\title{
SPINK1 Gene
}

National Cancer Institute

\section{Source}

National Cancer Institute. SPINK1 Gene. NCI Thesaurus. Code C18448.

This gene plays a role in the negative regulation of proteolysis. 